\title{
Peculiarities of Manipulative Strategies in English Political Discourse
}

\section{Samvel Abrahamyan}

Yerevan State University

\begin{abstract}
The article discusses peculiarities of manipulative strategies in English political discourse. Manipulative strategy can be considered as a form of persuasive strategy aimed at influencing hearers and making them accept beliefs or do things advocated by the manipulator. Manipulation can be considered effective when the hearer doesn't recognize the intentions of the speaker to influence him. Manipulation is realized by means of different strategies. The two most important ones are the strategy of positive self-presentation which aims at maximizing the significance of one's own status and the strategy of negative other-presentation which aims at creating a negative image of the opponent, discrediting him. An equally important manipulative strategy often used in political discourse is the theatrical strategy which is characterized by a very high level of emotionality and aims at forcing emotional responses on behalf of the hearers. In the article linguistic means of realization of manipulative strategies and tactics are revealed and discussed.
\end{abstract}

Key words: manipulative strategies, persuasive strategy, political discourse, evaluative argumentation, pragmatic markers of manipulation, rhetorical devices, social media.

\section{Introduction}

One of the peculiar features of political discourse is its manipulative character. Manipulation can be considered as a form of persuasive strategy aimed at influencing hearers in the best interests of the speakers. According to T. van Dijk, the crucial difference is that in persuasion the interlocutors are free to 
believe or act as they please, depending on whether or not they accept the arguments of the persuader, whereas in manipulation "recipients are unable to understand the real intentions or to see the full consequences of the beliefs or actions advocated by the manipulator" (Dijk 2006).

T. van Dijk in his work Discourse and Manipulation (2006) examined some properties of manipulation in a triangular theoretical framework which includes discourse, cognition and society. A discourse analytical approach is warranted because most manipulation takes place by text and talk. Secondly, those being manipulated are human beings, and this typically occurs through the manipulation of their 'minds', so that a cognitive account is also able to shed light on the processes of manipulation. Thirdly, manipulation is a form of talkin-interaction, and since it implies power and power abuse, a social approach is also important. Consequently manipulation can be revealed only by using an integrated complex approach which will include the analysis of all the three above mentioned aspects. Detecting manipulation is mainly the task of the researcher as the manipulator himself will never admit that he is engaged in manipulating people and very often manipulative techniques can be used unconsciously while the speaker tries to solve his/her immediate communicative goals. One of the effective means of revealing manipulation and resisting it is adopting a critical approach to the delivered information which is successfully done by the representatives of the critical discourse analysis.

\section{Manipulative Strategies in Political Discourse}

Manipulation in political discourse is realized by means of applying certain manipulative strategies which $\mathrm{T}$. van Dijk divides into two main groups, namely the strategy of positive self-presentation and the strategy of negative otherpresentation (Dijk 2006:373). In linguistic literature these two strategies are also defined as the strategy of downplay which aims at creating a negative image of the opponent, discrediting him, and the strategy of intensification which aims at maximizing the significance of one's own status. To these so called macro strategies the theatrical strategy should also be added (Mikhaleva 2009). This strategy, which is characterized by a very high level of emotionality, is singled 
out by the researchers due to the fact that in order to attract potential supporters politicians very often have "to work on the public". In their turn the public or the people being a part of the communication very often perceive the political discourse as a performance staged for them (Sheigal 2000:85).

Within these three macro strategies other substrategies can also be mentioned. For instance, P. Chilton speaking about strategic functions of the political discourse singles out three strategies, namely coercion, legitimization / delegitimisation, representation / misrepresentation. They are interconnected and in all of them elements of coercion and manipulation achieved by a strategic use of the language can be found. For instance, linguistic functions of coercion can be manifested in setting agendas, selecting topics in conversation, positioning the self and others in specific relationships, making assumptions about realities that hearers are obliged to at least temporarily accept, in order to process the text or talk. Another impo can be found rtant language-related phenomenon that could be judged coercive is the strategic stimulation of affect. According to P. Chilton, "it is reasonable to hypothesise links between meaning structures produced via discourse and the emotional centres of the brain" (Chilton 2004: 118). The legitimisation function is closely linked to coercion, because it establishes the right to be obeyed, that is, 'legitimacy'.

Reasons for being obeyed have to be communicated linguistically, whether by overt statement or by implication. The techniques used include arguments about voters' wants, general ideological principles, charismatic leadership projection, boasting about performance and positive self-presentation. What legitimacy means, writes $\mathrm{P}$. Chilton, is that humans using language politically seem to feel a strong pressure to justify their actions or proposals for action in terms of oppositions between right and wrong (Chilton 2004:120). At the heart of what is called 'politics' is the attempt to get others to 'share a common view' about what is useful-harmful, good-evil, just-unjust. And language is the only means for doing this. Delegitimisation is the essential counterpart: others (foreigners, enemies, institutional opposition, unofficial opposition) have to be presented negatively, and the techniques include the use of ideas of difference and boundaries, and speech acts of blaming, accusing, insulting, etc. 
Representation / misrepresentation relates to one of the obvious functions of discourse (language) - representing a reality which is in fact a matter of the control of information or discourse control. It may be quantitative or qualitative. Secrecy is the strategy of preventing people from receiving information; it is the inverse of censorship, which is preventing people from giving information. In another mode of representation/misrepresentation, information may be given, but be quantitatively inadequate to the needs or interests of hearers (telling the half-truth). Qualitative misrepresentation is simply lying, in its most extreme manifestation, but includes various kinds of omissions, verbal evasion and denial. Euphemism has the cognitive effect of conceptually 'blurring' or 'defocusing' unwanted referents, be they objects or actions. Implicit meanings of various types also constitute a means of diverting attention from troublesome referents (Chilton 2004:7-8).

Manipulative strategies and relevant tactics intended for the implementation of the formers can also be used to realize persuasive functions depending on the speaker's goals and intentions. Since the chief aim of manipulative strategies is to persuade the listener, they can be considered as a part of the persuasive strategy, which can be considered a generic term for manipulative strategies.

Among the main strategies of political discourse fulfilling manipulative functions the generic strategy of reductionism should be singled out. The strategy of reductionism is used to describe to an electorate a complex phenomenon in terms of other simpler phenomena without paying attention to its different aspects. This oversimplification lies in the basis of the bipolar type of estimation peculiar for political discourse where there is no zone of transitional or neutral signs and definitions. Accordingly the cognitive model of the reality is presented as extremely polarized, having no nuances, roughly divided into "us" and "them", "black" and "white", "good" and "bad", etc. The strategy of reductionism also lies in the basis of the ample use by politicians of such tropes as metaphors, metonymies, allegories, etc. which explain one phenomenon by means of the other. 
As already mentioned, the manipulative communication can be successful only if the hearer fails to recognize the influential intention of the speaker to make the former think and act in favor of the latter and against his own will. This goal is achieved by different manipulative techniques. The main principle of these techniques is to affect the subconscious of the addressees in order to alter their picture of the world, their evaluations and preferences and by doing it influence their behaviour and actions.

As the subconscious of the addressee can't be reached by rational and descriptive argumentation, politicians very often resort to irrational and evaluative arguments, make use of emotionally coloured words and expressions, conversational formulas and structures, different stylistic devices aimed at evoking emotional responses in the audience.

Among words with positive connotation often used by politicians are such words as freedom, democracy, justice, progress, change, new, etc. Other evaluative arguments used by politicians to exert influence on the audience include such emotional arguments as love, sense of duty, sense of dignity, pride and allegiance. These arguments inspire people and like interests and needs can underlie their actions. For instance, in his speech to accept the Republican nomination for president D. Trump said:

Remember, all of the people telling you you can't have the country you want are the same people that wouldn't stand, I mean, they said Trump does not have a chance of being here tonight, not a chance, the same people. Oh, we love defeating those people, don't we? Don't we love defeating those people? Love it. Love it. Love it.

The same argumentation was used by him in his victory speech:

We're going to get to work immediately for the American people. And we're going to be doing a job that hopefully you will be so proud of your president. You'll be so proud. Again, it's my honor. It was an amazing evening. It's been an amazing two-year period. And I love this country. 
Evaluative arguments, especially ones that appeal to moral and ethical values confirmed by time-honored traditions, are often used by politicians as a means of justification of their policy. Together with them an important role in manipulative strategies is assigned to evaluative arguments which contain mainly populist promises about things considered useful or profitable for different parts of society. These promises, which are manifestations of the theatrical strategy, are accompanied by words and expressions directed to evoking in the listeners positive feeling towards the speaker (trust, sympathy, loyalty, etc.). That's why politicians very often instead of presenting facts, figures and other analytical information speak about their beliefs, hopes and visions appealing to the feelings of the listeners and trying to make them believe in what they say they believe. For instance, in his acceptance speech at the Republican Convention D. Trump repeated the imperative expression "Believe me" for six times. This claim was enhanced by such sentences as "America is a nation of believers, dreamers and strivers" and "we must choose to believe in America".

To create the effect of unity and general support the strategy of solidarity is often used. An important part in it is assigned to such argumentative tactics as the use of the pronoun of solidarity we in inclusive meaning, opening addresses at the beginning of a speech (my fellow citizens, distinguished quests, fellow Americans, etc.), calling by the name as an expression of solidarity and friendship, etc. As a means of expressing solidarity the personal pronoun in the first person plural in the construction Let us is often used which helps to create an atmosphere of mutual understanding and trust, sharing a common goal. Speaking of himself in the third person is another manipulative device within the same strategy of self-representation. Sometimes it is done explicitly:

...that will never happen with Donald Trump as president"; and sometimes also implicitly. "Our Country Needs a Truly Great Leader... We need a leader that wrote "The Art of the Deal". We need a leader that can bring back our jobs.... 
Within the framework of the strategy of positive self-representation an important role is assigned to the use of epithets which perform evaluative function, e.g. good, best, smart, very nice, etc. (I think I'm actually a very nice person). Against this background the strategy of downplay is actively used to accentuate negative information about speaker's opponents and their policy.

Very often different manipulative strategies are used parallel to one another. For instance, in his speech to accept the Republican nomination for president $\mathrm{D}$. Trump actively used the strategy of downplay to show the negative results of Obama's policies: "President Obama has almost doubled our national debt to more than $\$ 19$ trillion and growing. And yet, what do we have to show for it?". Telling the audience that the country was in a crisis he supported his thesis by the following gloomy images: "Our roads and bridges are falling apart, our airports are third-world condition, and 43 million Americans are on food stamps". According to D. Trump, there were also a lot of unsolved problems in the sphere of foreign policy:

Now, let us consider the state of affairs abroad. Not only have our citizens endured domestic disaster, but they've lived through one international humiliation after another, one after another... After 15 years of wars in the Middle East, after trillions of dollars spent and thousands of lives lost, the situation is worse than it has ever been before. This is the legacy of Hillary Clinton: death, destruction, terrorism and weakness.

Another example of the strategy of reduction is "rule of three" actively used in political discourse to communicate complex ideas in a short, pervasive and memorable way. For instance, speaking about the threat of terrorism D. Trump proposed three steps to protect the country from it:

To protect us from terrorism, we need to focus on three things. We must have the best, absolutely the best gathering 
of intelligence anywhere in the world. The best. We must abandon the failed policy of nation-building and regime change that Hillary Clinton pushed in Iraq, in Libya, in Egypt and in Syria. Instead, we must work with all of our allies who share our goal of destroying ISIS and stamping out Islamic terrorism and doing it now, doing it quickly. We're going to win, we're going to win fast!

Within the strategy of positive self-presentation he assured the audience that he was the only person who could solve the problems facing the country ("Nobody knows the system better than me, which is why I alone can fix it") and that he had a plan which would bring the country out of the "disastrous" situation and "make it great again". He tried to assure his audience that as a result of his "new economic policies, trillions and trillions of dollars will start flowing into our country". He promised that "this new wealth will improve the quality of life for all Americans. We will build the roads, highways, bridges, tunnels, airports and the railways of tomorrow. This, in turn, will create millions of more jobs".

In his speech he also promised to pay a special attention to immigration policy and to relieve the country from uncontrolled immigration. Using the tactics of opposing himself to his rival he said that he would restore "law and order" to the country while H. Clinton's plan was proposing "mass lawlessness":

My plan is the exact opposite of the radical and dangerous immigration policy of Hillary Clinton. Americans want relief from uncontrolled immigration, which is what we have now. Communities want relief, yet Hillary Clinton is proposing mass amnesty, mass immigration and mass lawlessness.

(Donald Trump's Acceptance Speech)

Following the theatrical strategy, D. Trump actively used argumentation expressed in speech acts of promise addressed to different layers of society. The 
promises contained in his speech and ranging from reduction of taxes and creation of new jobs to leading "our country back to safety, prosperity and peace" touched upon the needs and interests of the vast majority of people and were intended to motivate them to vote for him.

One of the most important rhetorical devices producing manipulative effect are repetitions. The active use of the tactics of repetition is based on the assumption that people easily believe in what the politicians say even against their will (Sornig 1989). That's why politicians during their speeches very often address the audience to get confirmation of their words. In addition to that as a means of manipulation such methods and techniques are often used as semantic presuppositions, interrogative constructions with implicit semantics (special and rhetorical questions), appeals to the authority and to the fund of general knowledge, argumentation based on the proposition of conditional sentences to underline the cause-and-effect relations.

It should be taken into account that the evaluative argumentation in political discourse in the framework of the opposition "us - them" is very often conducted implicitly. Imposition of propositions is one of the effective methods of speech influence and manipulation. As the proposition is linguistically hidden in the structure of the sentence and is presented as initial information, it doesn't become the subject of critical analysis on the part of the recipient. It is so because presuppositional information is considered to be true, not requiring verification, otherwise the sentence will become anomalous and meaningless. It is also known that the knowledge given implicitly and contained in the logical premises and presuppositions of the utterance is learned better than the one which is explicitly represented in the proposition (Baranov 1990).

Communicative strategies and tactics of political discourse are called to provide the effectiveness of speech influence. The aim of communicative acts in political discourse is to influence the audience and to induce it to some actions which correspond to the aims and intentions of the sender of the message. For political discourse, the main goal of which is to influence the addressee, the perlocutive act is the main one in the structure of the speech act. It represents a purposeful influence on the thoughts and actions of the recipient and provokes 
the change in the interlocutor's consciousness and relevant reaction (amazement, discontent, fear, anger, etc.).

For example, the following extract from D. Trump's speech intends to evoke in listeners a sense of mistrust towards the policy of democrats on immigration issue and even fear towards the immigrants themselves:

When Mexico sends its people, they're not sending their best. They're not sending you. They're not sending you. They're sending people that have lots of problems, and they're bringing those problems with us. They're bringing drugs. They're bringing crime. They're rapists. And some, I assume, are good people. But I speak to border guards and they tell us what we're getting. And it only makes common sense. It only makes common sense. They're sending us not the right people. It's coming from more than Mexico. It's coming from all over South and Latin America, and it's coming probably probably-from the Middle East. But we don't know. Because we have no protection and we have no competence, we don't know what's happening. And it's got to stop and it's got to stop fast.

Using P. Chilton's terminology we can say that in terms of speech acts, Trump is issuing warnings; in terms of contextualised political language use, he is using a coercive strategy in so far as he is causing or inducing fear of contingent events and actors involved in them. P. Chilton distinguishes two kinds of coercion in the analysis, one forcing emotional responses, the other cognitive responses. Emotive coercion can occur when certain vocabulary or certain propositions receive mental representations that are in some way linked to emotion centres of the brain. For instance, some kind of fearful response may be stimulated by such terms as 'urgency', 'national danger' and 'evil', terms which are widely used by politicians. The second kind of coercion is propositional rather than emotive, and involves different forms of implied 
meaning. The mechanisms of 'forced inferences' include presupposition, implicature and presumptions (Chilton 2004:118-119).

One of the important manifestations of manipulation is the conversationalisation of political discourse. The manipulative and pragmatic effect of communication becomes apparent in the choice of such style of speech which can have the strongest influence on the audience. Analysing D. Trumps speeches we can see that he widely uses colloquial lexis, simple, short sentences, typical of his Twitter style, lexical and syntactic repetitions, parallel syntactic constructions, inversions, parcellations and elliptical structures. This, on the one hand, creates an effect of something unusual, extraordinary and helps to attract the attention of the audience, and, on the other hand, secures greater emotional influence and makes comprehension and memorization easier. The wide use of such linguostylistic means as epithet, especially in the context of opposition we - they (smart - stupid), hyperbole ( $I$ will be the greatest jobs president that God ever created), short evaluative judgments (Not good), colloquial lexis and style allows to secure necessary pathos and dynamics of speech and shortens the distance between him and the audience making his speeches understandable for ordinary voter.

P. Furko singles out special pragmatic markers of manipulation manifesting such manipulative intent as suppression, polarization, recontextualising, conversationalisation and intended ambiguity. Among them he singles out such pragmatic markers as of course, surely, I think, well, etc. It is noted that a single pragmatic marker can serve several manipulative functions, while a given manipulative strategy is potentially realized by a variety of pragmatic items. For instance, such evidential markers as of course, surely can be used both for suppression and backgrounding, they can signal the degree of confidence, positive or negative, held by the speaker about the truth of the basic message. They can indicate a speaker's attitude regarding the validity of certain information, for example, whether it is certain, probable, or untrustworthy. Such general extenders as and stuff (like that), and the like, and so on, et cetera might imply that there is more to be said on a certain issue than the speaker has said, and on the other hand they can downplay alternative viewpoints and policies. 
Quotations can play their relevant role in decontextualising and recontextualising texts, legitimising one's own opinion and delegitimising that of the opponent and thus justifying polarization between "them" and "us".

Such pragmatic markers of manipulation as I think, I mean can be manifestations of both conversationalisation and the exploitation of ambiguity. The wide use of conversational style in political discourse, including the above mentioned markers, is an effort to impress the audience, to influence them more easily. At the same time their wide use in political discourse is another manifestation of its ambiguity and manipulative intent. For instance, such manipulative pragmatic marker as $I$ think can fulfill two distinct and contrastive functions, expressing either uncertainty or certainty. From the social class perception in Britain it can mark certainty for the middle-class audience, and solidarity among members of the working class (Furko 2017).

Not only common people lacking appropriate information or experience but also politicians and even the whole political institutions can be manipulated for this or that reason. For instance, as it was shown by T. van Dijk, even such a powerful parliament like that of the UK was manipulated into accepting the Prime Minister's policy of joining the USA in war against Iraq that was presented as a war against tyranny and terrorism. What in reality was (among many other things) getting control with the USA of a key oil country in the Middle East, using as an excuse alleged weapons of mass destruction and the support of terrorism, was presented as defending democracy and the whole 'free' world against its major threat. As T. van Dijk argues, T. Blair managed to define the situation in such a way that few MPs could refuse, even when they knew they were being manipulated and probably lied to (Dijk 2006:380).

One of the main means of manipulation in political discourse is the creation and the use of the effect of a crowd whose actions contrary to those of individuals are determined by the collective unconscious. As the crowd acts on the basis of irrational factors, beliefs, convictions and emotions it becomes extremely suggestible and is easily manipulated. Here the crowd doesn't mean the accumulation of people in one place, but the human totality possessing a psychic community. It is achieved by means of mass media which has an access 
to every family and makes each person a member of this newly formed mass of people, a variety of the crowd (Lebon1995; Moskovichi 1998).

Nowadays different social media including Twitter, Facebook and other social networks are increasingly being used within the sociopolitical domain as a channel through which to circulate information and opinions. Throughout the 2016 US Presidential primaries and general election campaign, a notable feature was the prolific Twitter use of Donald Trump as a means of direct contact with voters. This use has continued since his election victory and inauguration as President. Donald Trump's Twitter style characterized by simple, short and imperative sentences, energetic, impressive and colourful language is especially suitable for inspiring people and driving them to corresponding actions.

Analyzing Donald Trump's Twitter discourse George Lakoff revealed a number of strategies which had certain manipulative aims. Among these strategies he singled out the following ones: Pre-emptive framing the purpose of which is to be the first to frame an idea; Diversion whose purpose is to divert attention from real issues; Deflection with the purpose to attack the messenger and change direction; Trial balloon with purpose to test public reaction (Ross and Rivers 2018).

In their investigation A.S. Ross and D.J. Rivers revealed that D. Trump most frequently uses the strategy of deflection the main purpose of which is labeling main stream media as 'fake news' and 'fake media' and positioning himself as the only reliable source of truth. The following tweet by Trump can serve as an example of the above-mentioned strategy:

54\% in Poll! I would be at 75\% (with our great economy, maybe the best ever) if not for the Phony Witch Hunt and the Fake News Media!

(<https://twitter.com/realDonaldTrump $>)$

As it is seen from this example, D. Trump, being under the permanent attacks on behalf of the establishment and mainstream media, in his turn resorts 
to the facts which can't be verified. However, his success at 2016 presidential elections proved the effectiveness of his persuasive and manipulative strategies which included a large use of social media and particularly Twitter as a means of direct contact with the voters with the aim of influencing and persuading them.

\section{Conclusion}

The polarization strategy (we/they) with the usual polarized structures of positive self-presentation and negative other-presentation lies in the basis of manipulation. Manipulative strategies are realized through different linguistic means. Not only rational but also irrational arguments, including emotional appeals, are used to produce a manipulative effect. Linguistic strategies and tactics of political discourse are called to influence the thoughts and actions of the recipient, and by provoking a change in the interlocutor's consciousness, evoke certain reaction. From this point of view manipulative strategies and tactics explicitly or implicitly represent varieties of coercive influence on the recipient, which contradicts the cooperation principle and maxims of effective communication.

Our analysis of various discursive dimensions of manipulation reveals that one of the peculiar features of political discourse is the usual polarized structure of positive self-presentation and negative other-presentation. In addition, we found out that in manipulative strategies emotional appeals and the use of evaluative arguments prevail over descriptive ones. Though the latters are also used as a means of confirmation of the speaker's ideas, the verification of them is not always possible. In political discourse manipulation includes not only cognitive and discursive aspects but also the social one because to be distinguished from other forms of influence political discourse should be first socially defined as a form of struggle for power, control and domination. That's why the study of different manifestations of manipulative social practices is very important to understand the mechanisms of speech manipulation in political discourse and try to resist it. 


\section{References:}

1. Baranov, A.N. (1990) Lingvisticheskaja teorija argumentatsii (kognitivnyj podkhod): Avtoref. diis. dokt. filol. nauk. M., $48 \mathrm{~s}$.

2. Chilton, P. (2004) Analysing Political Discourse: Theory and Practice. London: Routledge, $224 \mathrm{p}$.

3. Dijk, T.A. van. (2006) Discourse and Manipulation // Discourse \& Society, vol. 17 (2), p. 359-383.

4. Furko, P. (2017) Manipulative Uses of Pragmatic Markers in Political Discourse. // Palgrave Communications, volume 3, Article number: 17054. Available at: <https://www.nature.com/articles/palcomms201754> [Accessed June 2019].

5. Lebon, G. (1995) Psikhologija narodov i mass. SPb.: Maket, $311 \mathrm{s.}$

6. Mikhaleva, O.L. (2009) Poloticheskij diskurs: spetsifika manipuljativnogo vozdejstvjia. M.: Knozhnij dom «LIBROKOM», 256 s.

7. Moskovichi, S. (1999) Vek tolp. Istoricheskij traktat po psikhologii mass. M.: Tsentr psikhologii i psikhoterapii, $480 \mathrm{~s}$.

8. Ross, A.S. and Rivers, D.J. (2018) Discursive Deflection: Accusation of "Fake News" and the Spread of Mis- and Disinformation in the Tweets of President Trump. // Social Media + Society, April-June, p.1-12.

9. Sheigal, E.I. Semiotika politicheskogo diskursa. M.: ITDGK «Gnozis», $326 \mathrm{s.}$

10. Sornig, K. (1989) Some Remarks on Linguistic Strategies of Persuasion. // Language, Power and Ideology: Studies in Political Discourse. Ed. by Ruth Wodak. Amsterdam, Philadelphia: John Benjamins Publishing Company, p. 95-113.

\section{Sources of Data:}

1. Donald Trump's Acceptance Speech at the Republican Convention, July 22, 2016. Available at: <https://time.com/4418493/republican-conventiondonald-trump-transcript $>$ [Accessed June 2019]. 


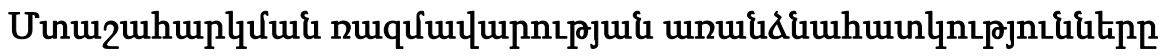 uiqquiltiqne punupulquí npulpnıpunıu}

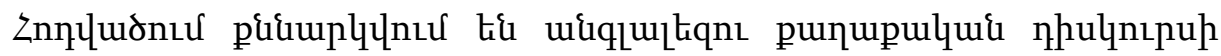

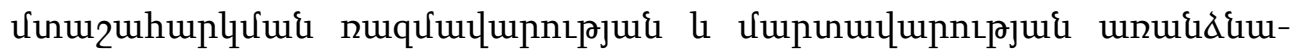

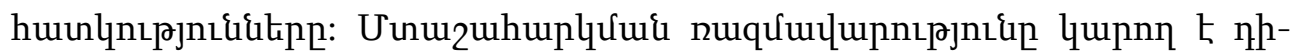

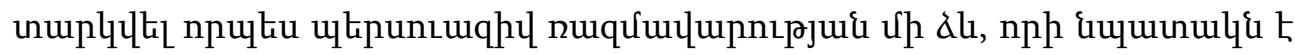

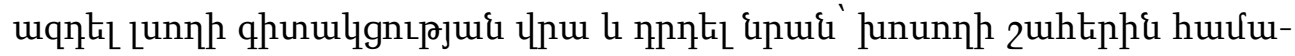

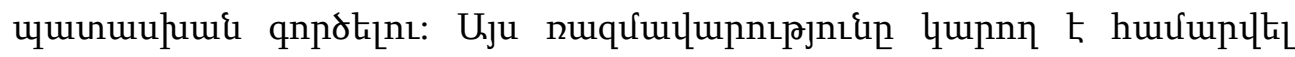

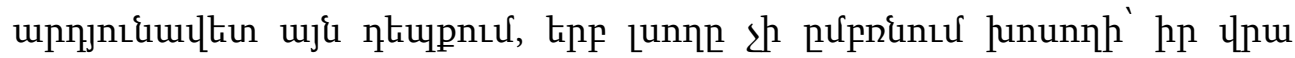

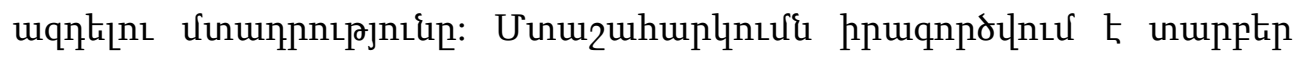

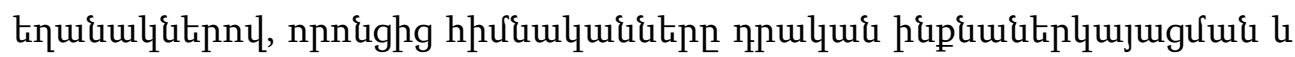

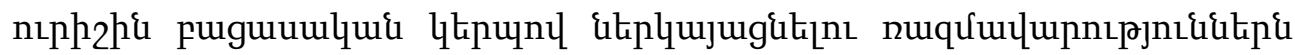

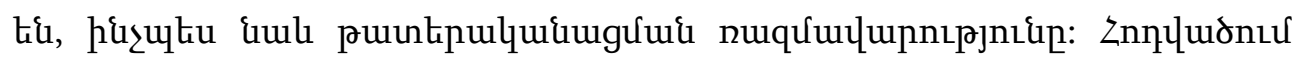

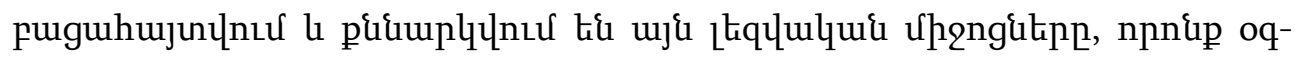

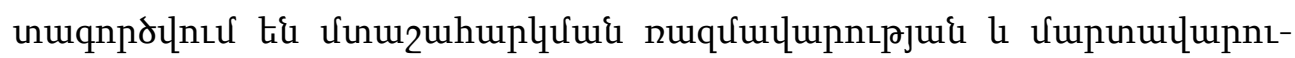
pJui hpuqnporumi hưưp:

Received by the Editorial Board 25.09.2019

Recommended for publication by the reviewers 26.11.2019

Accepted for print 03.02.2020 